\title{
Catheter Related Leuconostoc Mesenteroides Bacteremia: A Rare Case and Review of the Literature
}

\author{
Kateter Illișkili Leuconostoc Mesenteroides Bakteriyemisi: Nadir Bir Olgu \\ ve Literatürün Derlenmesi
}

\author{
Adem Karbuz1, Bilge Aldemir Kocabaş1, Aytaç Yalman2, Zarife Kuloğlu2, Ahmet Derya Aysev3, \\ Ergin Çiftçi1, Erdal İnce1 \\ ${ }^{1}$ Ankara University Faculty of Medicine, Department of Pediatrics, Division of Pediatric Infectious Diseases, Ankara, Turkey \\ ${ }^{2}$ Ankara University Faculty of Medicine, Department of Pediatrics, Ankara, Turkey \\ ${ }^{3}$ Ankara University Faculty of Medicine, Department of Clinical Microbiology, Ankara, Turkey
}

\begin{abstract}
Herein we report the successful treatment of catheter related blood stream infections due to Leuconostoc mesenteroides with antibiotic lock therapy in addition to systemic treatment. With our case, we have shown that in the presence of catheter related blood stream infections, antibiotic lock therapy can be used as a therapeutic option to get successful results if the catheter cannot be removed or there are still positive cultures despite the systemic antibiotic therapy.

Keywords: Leuconostoc mesenteroides, catheter related bacteremia, antibiotic lock therapy
\end{abstract}

\section{ÖZ}

Leuconostoc mesenteroides'e bağı kateter ilişkili kan akımı enfeksiyonunun sistemik tedaviye ilaveten antibiyotik kilit tedavisi ile başarı bir şekilde tedavi süreci anlatıldı. Sunulan olguyla kateter ilişkili kan akımı enfeksiyonu varlı̆̆ında eğer kateter çıkartllamıyor ve sistemik antibiyotik tedavisine rağmen üreme devam ediyorsa antibiyotik kilit tedavisinin uygulanabileceği ve başarılı sonuç alınabileceği gösterildi.

Anahtar Kelimeler: Leuconostoc mesenteroides, kateter ilişkili enfeksiyon, antibiyotik kilit tedavisi

\section{Introduction}

Advances in the field of microbiology and awareness among the microbiologists led to an increase in the rate of identification of rare opportunistic microorganisms in humans. Leuconostoc species are catalase negative, facultative anaerobic gram positive cocci configured in doubles or chains. They are usually found in plants, dairy products, wine and food. They are initially believed to be a member of the flora of vagina and gastrointestinal system $(1,2)$. In recent years, many case reports of serious infections led to an increased awareness and focus on risk factors, pathogeneticity and treatment options.

This case report documents the successful treatment of catheter associated blood stream infection due to Leuconostoc bacteria with antibiotic lock treatment in addition to systemic antibiotic treatment. This is a novel approach in cases where catheter removal is not an option because of 
Karbuz et al.

Catheter Related Leuconostoc Bacteremia

the lack of alternative intravenous line. To our knowledge, it is the first known report of Leuconostoc mesenteroides bacteremia successfully treated with antibiotic lock therapy.

\section{Case Report}

A fifty-day-old girl was admitted to pediatric gastroenterology department with chronic diarrhea. She had complaints of diarrhea and vomiting for two weeks. Following diagnostic endoscopy, she suffered from a duodenum perforation. A central catheter was placed at the surgery. After the operation, piperacillin-tazobactam, teicoplanin and fluconazole were given as an empirical therapy. Total parenteral nutrition (TPN) was initiated. Her fever began five days later from the cessation of empirical antibiotic therapy. Laboratory workup revealed white blood cell count 13.700/ $\mathrm{mm}^{3}$, hemoglobin $9.8 \mathrm{~g} / \mathrm{dL}$, platelet count 328.000/. $\mathrm{mm}^{3}$, C-reactive protein: $22 \mathrm{mg} / \mathrm{dL}$. Blood cultures were taken, empirical fluconazole and cefoperazone-sulbactam were initiated. As fever continued, teicoplanin was added on the second day. Amikacin was added on the third day because her appearance became worsened. Although initial blood cultures remained sterile, blood cultures taken on the third day of the therapy were positive for gram positive cocci. She had an intractable fever exceeding $39^{\circ} \mathrm{C}$. Leuconostoc mesenteroides were identified in addition to coagulase negative Staphylococcus on the seventh day of therapy. The signal for growth of Leuconostoc was detected at $5^{\text {th }}$ and $13^{\text {th }}$ hours from the catheter culture and peripheral vein culture, respectively. Teicoplanin was discontinued on the 6th day and high dose linezolid and ampicilline were initiated. Catheter lock therapy was planned but the central line was accidentally removed. As no other vascular access could be obtained, another central catheter was placed despite ongoing bacteremia. Echocardiography was negative for valvular vegetations. Abdominal ultrasonography revealed ascites. Cultures of peripheral blood and catheter remained positive for Leuconostoc. The signal for growth of Leuconostoc was detected from the catheter culture and the peripheral vein culture at $13^{\text {th }}$ and $28^{\text {th }}$ hours, respectively. Antibiotic lock therapy was re-initiated on the $12^{\text {th }}$ day of fever. On the third day of antibiotic lock therapy, her fever resolved, and cultures remained sterile. Rectal cultures were positive for Escherichia coli. After systemic antibiotherapy for three weeks, antibiotic lock therapy for 2 weeks and full enteral feeding, she was discharged from the hospital.

\section{Discussion}

Leuconostoc spp. is a member of Streptococcaceae family. It is not an easily recognized microorganism by routine biochemistry and phenotypical identification. As it is a nonhemolytic or alfa-hemolytic gram positive coccus on sheep agar, it may be mistaken for Enterococcus or Streptococcus (3). Like Enterococci it may reproduce in $6.5 \% \mathrm{NaCl}$ and hydrolysis esculin in the presence of bile. Leuconostoc species are incapable of producing leucine aminopeptidase and pyrrolidonyl arylamidase. $\mathrm{CO}_{2}$ formation with glucose are distinctive properties while not a part of routine investigations in many microbiology labs. Antibiotic sensitivity tests are important for identification. Leuconostoc species are naturally glycopeptide resistant (1). In our case, blood cultures revealed non-hemolytic gram positive cocci, forming short chains mostly in doubles which were initially thought to be Streptocci. Antibiotic sensitivity test showed sensitivity to ampicillin and penicillin but resistance to vancomycin, it was suspected from Leuconostoc species. A verification was performed using BD phoenix 100 version 6.01A. Result was $99 \%$ consistent with Leuconostoc mesenteroides spp. mesenteroides.

Leuconostoc species were not considered as pathogens for humans until early eighties. The first report as human pathogen was by Buu-Hoi et al. (4) in 1985. Two cases with blood cultures which had gram positive cocci resistant to vancomycin were reported. They were initially identified as Streptococci by API 20 Strep system but gas production from glucose and fermentation status of various carbohydrates led to the identification of Leuconostoc species (4). Leuconostoc has been accepted as the etiologic agent for bacteremia, sepsis, catheter related blood stream infection, meningitis, endocarditis, brain and liver abscess, osteomyelitis, pulmonary and nosocomial infections (1,3,59). Sixty percent of Leuconostoc case reports between 1985 and 1996 were of children (10). Most of the patients presenting with Leuconostoc were immunocompromised patients (malignancy, liver transplantation, chemotherapy, immunosuppression) (10-13). However, some patients with Leuconostoc infection were immunocompetent (14). Other risk factors among published reports were gastrointestinal disease, prior vancomycin therapy, surgery distrupting gastrointestinal mucosal integrity, TPN usage, central venous line, prematurity $(1,3,10,13,15)$.

Immunologic workup revealed no immune deficiency in our case. Chronic diarrhea, gastrointestinal surgery, vancomycin therapy, central venous catheter and TPN administration were important risk factors for Leuconostoc infection.

Even though Leuconostoc species are isolated from vaginal and fecal samples, they are not considered to be normal flora members. Site of entry is not clear in infections due to Leuconostoc species. Few reports speculate that the site of entry can be skin $(16,17)$. Co-infection with coagulase negative staphylococci raise the suspicion of entry through skin $(3,10,16)$. As most cases of Leuconostoc infection have central catheter, speculations about disrupted skin integrity during catheter insertion is the main cause $(3,16,17)$. Others speculate that gastrointestinal system is another entry site. They state that when the gastrointestinal system is colonized with Leuconostoc, translocation occurs $(3,15,16)$. In another report, 35 percent of cases have polymicrobial etiology, so intra-abdominal source may be suspected (13). Moreover, Leuconostoc species are isolated from infant formula, various foods, gastric aspirates, gastrostomy tubes 
Karbuz et al.

Catheter Related Leuconostoc Bacteremia

and these support the idea of gastrointestinal entry $(15,18)$. Apart from that, a report by Bou et al. (6) documents TPN as the source of nosocomial Leuconostoc infections. It is clear that in our case there are multiple risk factors. It is hardly possible to tell which factor has the leading role, but it may be speculated that gastrointestinal route is more probable case due to chronic diarrhea. Simultaneous resolution of diarrhea and infection supports this hypothesis.

Management of Leuconostoc infections consists of appropriate antibiotic therapy and removal of infection source (catheter removal, draining of abscess) (3). The most preferred antibiotic for Leuconostoc infections is penicillin with or without gentamicin. Minimum inhibitory concentration value of penicillin is higher than Streptococci mandating a higher dose or combination with an aminoglycoside $(3,10)$. In published reports, Leuconostoc infections are successfully treated by ampicillin, cefotaxime, carbapenem, clindamycin, erythromycin and recently by daptomycin $(1,3,19)$. The characteristics of pediatric patients who have gastrointestinal disease with Leuconostoc bacteremia is shown in Table I (3).

Management of catheter related bacteremia is not clear. In most cases of catheter related bacteremia, catheter removal has been required $(10,15)$. In three cases, bacteremia was resolved without antibiotic treatment following catheter removal $(10,16,17)$. Guideline for catheter related blood stream infections does not contain information about Leuconostoc (20). No information regarding biofilm formation of Leuconostoc was found. Former reports show a tendency towards catheter removal for the control of infection. In our case, linezolid and ampicillin therapy was initiated following the identification of Leuconostoc. Vascular access problem mandated antibiotic lock therapy but the central line was accidentally removed. Another central catheter was inserted immediately. Blood cultures remained positive and the second catheter was also colonized with Leuconostoc. Due to catheter related blood stream infection, positive blood cultures and persistence of systemic signs required antibiotic lock therapy. The combined lock solution was prepared by mixing ampicillin $10 \mathrm{mg} / \mathrm{mL}$ and heparin 5000 units $/ \mathrm{mL}$ for antibiotic lock therapy. Then, the solution was administered into the lumen of the catheter every 12 hours. Following lock therapy, blood cultures remained sterile and clinical signs improved. Systemic therapy with linezolid and ampicillin was continued for 21 days, while lock therapy lasted for 12 days. Three months follow-up revealed no problems.

Leuconostoc species should be kept in mind in cases of vancomycin resistant gram positive infections. Even though they are rare pathogens for humans, they may cause serious infections. In cases of catheter related blood stream infections where systemic antibiotic treatment fails and

\begin{tabular}{|c|c|c|c|c|c|c|c|c|}
\hline C & Age & Sex & Primary disease & TPN & CVC & Previously vancomycin therapy & Treatment & Line removal \\
\hline 1 & 6 months & $M$ & $\begin{array}{l}\text { Gastroschisis and bowel } \\
\text { infarction }\end{array}$ & + & + & - & Ampicillin (14 days) & No \\
\hline 2 & $\begin{array}{l}3 \text { years } 6 \\
\text { months }\end{array}$ & $F$ & Gastroschisis & + & + & Unknown & Ampicillin (14 days) & $\begin{array}{l}\text { Yes (venous } \\
\text { thrombosis) }\end{array}$ \\
\hline 3 & 6 months & $M$ & Necrotizing enterocolitis & + & + & Unknown & Penicillin (14 days) & Yes \\
\hline 4 & 11 years & $\mathrm{F}$ & $\begin{array}{l}\text { Midgut volvulus and } \\
\text { congenital malrotation }\end{array}$ & + & + & - & Ampicillin and gentamicin (14 days) & Yes \\
\hline 5 & 8 months & $F$ & Gastroschisis & + & + & - & Imipenem (14 days) & Yes \\
\hline 6 & 2 years & $\mathrm{F}$ & Jejunal atresia & + & + & + & Imipenem (17 days) & Yes \\
\hline 7 & 2 months & $F$ & Necrotizing enterocolitis & - & + & + & Vancomycin clindamycin(14 days) & Yes \\
\hline 8 & 1 months & M & Necrotizing enterocolitis & + & + & + & Penicillin (14 days) & No \\
\hline 9 & 9 months & $\mathrm{F}$ & Jejunal atresia & + & + & & Ampicillin + gentamicin (10 days) & No \\
\hline 10 & 20 months & $F$ & Necrotizing enterocolitis & + & + & + & Amoxicillin (14 days) & Yes \\
\hline 11 & 4 years & M & Malrotation and volvulus & + & + & + & Amoxicillin (14 days) & No \\
\hline 12 & 7 months & $F$ & $\begin{array}{l}\text { Gastroschisis, small bowel } \\
\text { and colonic atresia }\end{array}$ & + & + & + & Ampicillin + gentamicin & Yes \\
\hline 13 & 13 months & $F$ & Gastroschisis, jejunalatresia & + & + & + & Penicillin (14 days) & Yes \\
\hline 14 & 10 months & $M$ & Necrotizing enterocolitis & + & + & + & Ampicillin + gentamicin & No \\
\hline 15 & 1 years & $F$ & Jejunal atresia & + & + & + & Vancomycin + cefotaxime + metronidazole & Yes \\
\hline 16 & 8 months & $\mathrm{F}$ & $\begin{array}{l}\text { Hirschsprung and } \\
\text { intestinal obstruction }\end{array}$ & + & + & + & Clindamycin + amikacin (16 days) & Yes \\
\hline PC & 1 months & $\mathrm{F}$ & Chronic diarrhea & + & + & + & $\begin{array}{l}\text { Ampicillin + linezolid ( } 21 \text { days) } \\
\text { andampicillin lock therapy (14 days) }\end{array}$ & No \\
\hline
\end{tabular}


catheter removal is impossible, antibiotic lock therapy may be a therapeutic option.

\section{Ethics}

Informed Consent: Retrospective study.

Peer-review: Externally peer-reviewed.

\section{Authorship Contributions}

Medical Practices: Adem Karbuz, Bilge Aldemir Kocabaş, Aytaç Yalman, Zarife Kuloğlu, Ahmet Derya Aysev, Erdal Ince, Concept: Adem Karbuz, Design: Adem Karbuz, Data Collection or Processing: Adem Karbuz, Bilge Aldemir Kocabaş, Aytaç Yalman, Analysis or Interpretation: Ergin Çiftçi, Literature Search: Adem Karbuz, Writing: Adem Karbuz.

Conflict of Interest: No conflict of interest was declared by the authors.

Financial Disclosure: The authors declared that this study has received no financial support.

\section{References}

1. Arias CA, Murray BE. Enteroccus species, Streptococcus bovis group, and Leuconostoc species, In: Mandell GL, Bennett JE, Dolin R (eds), Mandell, Douglas and Bennett's Principles and Practice of Infectious Diseases. 7th ed. Churchill Livingstone, Philadelphia. 2010: p: 2643-52.

2. Rogasa M, Sharpe ME. Species differentiation of human vaginal Lactobacilli. J Gen Microbiol 1960;23:197-201.

3. Florescu D, Hill L, Sudan D, Iwen PC. Leuconostoc bacteremia in pediatric patients with short bowel syndrome: case series and review. Pediatr Infect Dis J 2008;27:1013-9.

4. Buu-Hoi A, Branger C, Acar JF. Vancomycin-resistant streptococci or Leuconostoc sp. Antimicrob Agents Chemother 1985;28:458-60.

5. Taşkapılıoğlu, O, Bahar A, Yılmaz E, et al. Nosocomial Leuconostoc Pseudomesenteroides Meningitis: A Case Report and Review of the Literature. Balkan Med J 2011;28:216-8.

6. Bou G, Luis Saleta J, Sáez Nieto JA, et al. Nosocomial Outbreaks Caused by Leuconostoc mesenteroides subsp. mesenteroides. Emerg Infect Dis 2008;14:968-71.

7. Wonga DW, Yang, W, Vielemeyer O. Catheter-Related Leuconostoc Bacteraemia in a Pregnant HIV-Infected Woman. J Med Cases 2012:3:331-3.

8. Kocak F, Yurtseven N, Aydemir N, Yüksek A, Yavuz SS. A case of osteomyelitis due to Leuconostoc lactis. Scand J Infect Dis 2007;39:278-80.
9. Ling ML. Leuconostoc bacteraemia. Singapore Med J 1992:33:241-3.

10. Dhodapkar KM, Henry NK. Leuconostoc bacteremia in an infant with short-gut syndrome: case report and literature review. Mayo Clin Proc 1996;71:1171-4.

11. Tholpady SS, Sifri CD, Sawyer RG, Hazen KC, Pruett $T L$, Bonatti H. Leuconostoc pseudomesenteroides blood stream infection following liver transplantation. Ann Transplant 2010;15:61-6.

12. Ishiyama $K$, Yamazaki $H$, Senda $Y$, Yamauchi $H$, Nakao S. Leuconostoc bacteremia in three patients with malignancies. J Infect Chemother 2011;17:412-8.

13. Lee MR, Huang YT, Lee Pl, et al. Healthcare-associated bacteraemia caused by Leuconostoc species at a university hospital in Taiwan between 1995 and 2008. J Hosp Infect 2011;78:45-9.

14. Casanova-Roman M, Rios J, Sánchez-Porto A, Gomar JL, Casanova-Bellido M. Leuconostoc bacteremia in a healthy infant. Minerva Pediatr 2003;55:83-6.

15. Janow G, Lambert B, Scheiner M, Rosen O, Goldman DL, Soghier L. Leuconostoc septicemia in a preterm neonate on vancomycin therapy: case report and literature review. Am J Perinatol 2009;26:89-91.

16. Handwerger $S$, Horowitz $H$, Coburn K, Kolokathis $A$, Wormser GP. Infection due to Leuconostoc species: six cases and review. Rev Infect Dis 1990;12:602-10.

17. Bernaldo de Quiros JC, Munoz P, Cercenado E, Hernandez Sampelayo T, Moreno S, Bouza E. Leuconostoc species as a cause of bacteremia: two case reports and a literature review. Eur J Clin Microbiol Infect Dis 1991;10:505-9.

18. Carapetis J, Bishop S, Davis J, Bell B, Hogg G. Leuconostoc sepsis in association with continuous enteral feeding: two case reports and a review. Pediatr Infect Dis J 1994;13:81623.

19. Golan Y, Poutsiaka DD, Tozzi S, Hadley S, Snydman DR. Daptomycin for line-related Leuconostoc bacteraemia. J Antimicrob Chemother 2001;47:364-5.

20. Mermel LA, Allon M, Bouza E, et al. Clinical Practice Guidelines for the Diagnosis and Management of Intravascular Catheter-Related Infection: 2009 Update by the Infectious Diseases Society of America. Clin Infect Dis 2009;49:1-45. 